\title{
Correction to: Successful implementation of isoniazid preventive therapy at a pediatric HIV clinic in Tanzania
}

Olivia F. Hunter ${ }^{1,2^{*}}$, Furaha Kyesi ${ }^{3}$, Amrit Kaur Ahluwalia', Zeinabou Niamé Daffé ${ }^{1}$, Patricia Munseri ${ }^{4}$, C. Fordham von Reyn ${ }^{5}$ and Lisa V. Adams ${ }^{6}$

\section{Correction to: BMC Infect Dis 20, 738 (2020) https://doi.org/10.1186/s12879-020-05471-z}

Following publication of the original article [1], the author identified an error in the author name of C. Fordham von Reyn.

The incorrect author name is: C. F. von Reyn.

The correct author name is: C. Fordham von Reyn.

The author group has been updated above and the original article [1] has been corrected.

\footnotetext{
Author details

'Dartmouth College, Hanover, NH 03755, USA. ${ }^{2}$ New York, USA. ${ }^{3}$ Ministry of Health, Community Development, Gender, Elderly, and Children, Dodoma, Tanzania. ${ }^{4}$ Muhimbili University of Health and Allied Sciences, Dar es Salaam, Tanzania. ${ }^{5}$ Dartmouth-Hitchcock Medical Center, Lebanon, NH 03756, USA.

${ }^{6}$ Geisel School of Medicine at Dartmouth, Hanover, NH 03755, USA.
}

Published online: 20 October 2020

\section{Reference}

1. Hunter, et al. Successful implementation of isoniazid preventive therapy at a pediatric HIV clinic in Tanzania. BMC Infect Dis. 2020;20:738 https://doi.org/ 10.1186/s12879-020-05471-z.

The original article can be found online at https://doi.org/10.1186/s12879020-05471-z

* Correspondence: olivia.frances.hunter@gmail.com

${ }^{1}$ Dartmouth College, Hanover, NH 03755, USA

${ }^{2}$ New York, USA

Full list of author information is available at the end of the article

(C) The Author(s). 2020 Open Access This article is licensed under a Creative Commons Attribution 4.0 International License, which permits use, sharing, adaptation, distribution and reproduction in any medium or format, as long as you give appropriate credit to the original author(s) and the source, provide a link to the Creative Commons licence, and indicate if changes were made. The images or other third party material in this article are included in the article's Creative Commons licence, unless indicated otherwise in a credit line to the material. If material is not included in the article's Creative Commons licence and your intended use is not permitted by statutory regulation or exceeds the permitted use, you will need to obtain permission directly from the copyright holder. To view a copy of this licence, visit http://creativecommons.org/licenses/by/4.0/ The Creative Commons Public Domain Dedication waiver (http://creativecommons.org/publicdomain/zero/1.0/) applies to the data made available in this article, unless otherwise stated in a credit line to the data. 